\title{
Expression of the Endothelin-axis in the different histologic subtypes of renal cell carcinoma: A tissue microarray analysis
}

\author{
EDWIN HERRMANN ${ }^{1}$, ELKE ELTZE ${ }^{2}$, STEFAN BIERER $^{1}$, MARTIN BOGEMANN $^{1}$, \\ OLAF ANSELM BRINKMANN ${ }^{1}$, HODA BALNOWAIR ${ }^{2}$, LOTHAR HERTLE $^{1}$ and CHRISTIAN WULFING ${ }^{1}$ \\ ${ }^{1}$ Department of Urology, and ${ }^{2}$ Institute of Pathology, University of Münster, \\ Albert-Schweitzer Strasse 33, 48149 Münster, Germany
}

Received August 30, 2006; Accepted October 2, 2006

\begin{abstract}
Endothelin-1 and its receptors $\mathrm{ET}_{\mathrm{A}} \mathrm{R}$ and $\mathrm{ET}_{\mathrm{B}} \mathrm{R}$, commonly referred to as the Endothelin-axis, are emerging to play a role in cancer. The Endothelin-axis has been shown to be involved in proliferation, angiogenesis and metastasis in various human tumours. To assess the role of the Endothelinaxis in renal cell carcinoma, we analysed its expression in archival tumour tissue of 183 patients. Representative tumour blocks were selected for constructing a tissue microarray. Paraffin sections were assessed immunohistochemically using monoclonal and polyclonal antibodies for Endothelin-1, $\mathrm{ET}_{\mathrm{A}} \mathrm{R}$ and $\mathrm{ET}_{\mathrm{B}} \mathrm{R}$. Staining intensities were analysed semiquantitatively and the results were correlated with various histopathologic factors. Overexpression of Endothelin-1, $\mathrm{ET}_{\mathrm{A}} \mathrm{R}$ and $\mathrm{ET}_{\mathrm{B}} \mathrm{R}$ was identified in $12.8 \%, 84.1 \%$ and $93.3 \%$ of cases, respectively. No association with pathological tumour stage and histologic grading was found. Papillary renal cell carcinomas expressed highly significantly more Endothelin-1 than clear cell renal cell carcinomas $(34.5 \%$ vs. $6.7 \%, \mathrm{p}<0.001)$, while there was no difference between $\mathrm{ET}_{\mathrm{A}} \mathrm{R}$ - and $\mathrm{ET}_{\mathrm{B}} \mathrm{R}$ expression in these histologic subtypes. However, $\mathrm{ET}_{\mathrm{A}} \mathrm{R}$ tended to be overexpressed in the subgroup of G3-tumours $(p=0.044)$. Studies are underway assessing the role of the Endothelin-axis and its potential use as a molecular target in renal cell carcinoma.
\end{abstract}

\section{Introduction}

In the last 50 years, the number of people diagnosed with renal cell carcinoma (RCC) has dramatically increased: it is estimated that the prevalence in the US has risen by $126 \%$ in this period. The American Cancer Society reported about

Correspondence to: Dr Edwin Herrmann, Department of Urology, University of Münster, Albert-Schweitzer Strasse 33, 48149 Münster, Germany

E-mail: herrmae@ukmuenster.de

Key words: endothelin axis, endothelins, endothelin receptors, renal cell carcinoma, immunohistochemistry, tissue microarray
31,900 new cases of cancer involving the kidney in 2003, and 35,710 in 2004. (1). The current classification system for RCC includes a number of histologic subtypes (2). The two most common ones are clear cell renal cell carcinoma (ccRCC), representing approximately $70-80 \%$ of patients, and papillary renal cell carcinoma ( $\mathrm{pRCC}$ ), which is observed in only $10-15 \%$ of patients $(2,3)$. Currently, radical nephrectomy is the therapeutic gold standard. However, the prognosis remains unfavourable, especially for metastatic disease (1). Therefore, molecular markers need to be determined to allow better discrimination of aggressive tumour phenotypes and to identify candidates for a targeted therapeutic approach in the future.

Among targets that have emerged to play an important role in tumour biology are the endothelins and their receptors. They consist of three small and multifunctional vasoconstrictor (21-amino acid) peptides: ET-1, ET-2 and ET-3. ET-1 is produced by a variety of normal cells, including endothelial cells, vascular smooth muscle cells and various epithelial tissues, while ET-2 is expressed mainly in intestine and kidney, and ET-3 in the brain (4). All of them exert their physiologic effect via two high-affinity, G-protein-coupled receptors, $\mathrm{ET}_{\mathrm{A}} \mathrm{R}$ and $\mathrm{ET}_{\mathrm{B}} \mathrm{R}$. The combination of $\mathrm{ET}-1$, the best characterised endothelin to date and the two receptors is referred to as the (Endothelin-) ET-axis. Kusuhara et al were the first to demonstrate ET-1 production in tumour cell lines (5), and since then a growing role for ET-1 in tumour biology has been postulated for several tumour entities $(6,7)$. By different mechanisms, ET receptor activation promotes tumour associated functions through $\mathrm{ET}_{\mathrm{B}} \mathrm{R}$ such as cell proliferation and migration, whereas stimulation of vascular smooth muscle, pericyte mitogenesis, and production of vascular endothelial growth factor (VEGF), which leads to endothelial cell proliferation and vascular permeability by increasing the levels of hypoxia-inducible factor (HIF)- $1 \alpha$, are predominantly accomplished by $\mathrm{ET}_{\mathrm{A}} \mathrm{R}$ (8-10).

Nelson et al were the first to show that ET-1 is a potentially important factor in advanced prostate cancer progression (11), which later led to initiating a randomized, placebo-controlled phase-II trial with Atrasentan (ABT-627), a selective $E_{\mathrm{A}} \mathrm{R}$ antagonist. In an intent-to-treat analysis of results, a trend towards prolongation of disease progression and a statistically significant delay in PSA progression were demonstrated (12). Recently, preliminary results were reported from phase-III 
trials with Atrasentan. They revealed a trend toward delayed time to progression and significantly delayed elevation of bone turnover markers (13).

In invasive bladder cancer, our group was able to report a high expression of the ET-axis at the mRNA and protein level (9). In a concomitant study we showed that both ET receptors were overexpressed, $\mathrm{ET}_{\mathrm{B}} \mathrm{R}$ predominating. Expression of $\mathrm{ET}_{\mathrm{B}} \mathrm{R}$ was associated with several parameters of favourable tumour types and a better prognosis as well as a longer diseasefree survival. To assess the role of $\mathrm{ET}_{\mathrm{A}} \mathrm{R}$ as a molecular target in bladder cancer, we carried out a preclinical study on bladder tumour xenografts with Atrasentan. Compared to the placebo group, a diminished growth rate with an increased percentage of necrosis in the tumour tissue was reported, although no significant cytoreduction was noted. Studies at our department are ongoing to evaluate the role of Atrasentan to serve future targeted molecular therapy. Results are expected in the near future.

To date, to the best of our knowledge, there have been published only three small reports about the expression of the ET-axis in RCC (14-16). Although the results showed activity for the ET-axis, they were not sufficient to define its role in RCC and the different histologic subtypes accurately and to evaluate ET-1 and its receptors to serve as potential molecular targets for further clinical trials. We therefore undertook this study to analyse the expression of the ET-axis and its impact on pathologic parameters in a large group of patients undergoing nephrectomy.

\section{Materials and methods}

Patients and tumour specimens. Patients $(\mathrm{n}=183)$ undergoing radical nephrectomy for RCC at our institution were included in the study. Men $(n=133)$ and women $(n=50)$ were operated on between 1991 and 2004; median age at surgery was 61 (range, 25-95) years. Histologic slides and formalin-fixed, paraffin-embedded tumour tissue blocks from all 183 patients were obtained from the files at the Institute of Pathology (University of Münster). All slides were reviewed, and representative tumour tissue blocks were selected for immunohistochemistry. A database comprising histopathologic data regarding tumour stage, histologic grading and histology type was created (Table I).

For each of the 183 cases we selected a representative tumour block as a donor block for the tissue microarray (TMA). Using an H\&E-stained slide, two morphologically representative regions were defined for each of the 183 tumour samples. From these regions, cylindrical core tissue specimens (diameter $=0.6 \mathrm{~mm}$ ) were obtained and arrayed precisely into a new recipient paraffin block (20x35 mm) using a custom-built precision instrument (Beecher Instruments, Silver Spring, MD). From the 366 tumour samples available, four tissue array blocks were prepared.

Immunohistochemistry for $E T-1, E T_{A} R$ and $E T_{B} R$. The paraffinembedded tumour tissue blocks were cut into $3-\mu \mathrm{m}$ slices and mounted on poly-L-lysine-coated glass slides. Tissue slides were dewaxed in xylene, rehydrated in a graded series of alcohol and rinsed in $0.01 \mathrm{M}$ Tris buffer ( $\mathrm{pH}$ 7.3). Immunohistochemical staining for ET-1, $\mathrm{ET}_{\mathrm{A}} \mathrm{R}$ and $\mathrm{ET}_{\mathrm{B}} \mathrm{R}$ was
Table I. Distribution of tumor size and histologic grade in the reported series of RCC specimens $(n=183)$.

\begin{tabular}{lc}
\hline \multicolumn{2}{c}{ Pathological parameters [n (\%)] } \\
Tumor stage $^{\mathrm{a}}$ \\
pT1 & $76(42.7 \%)$ \\
pT2 & $21(11.8 \%)$ \\
pT3 & $80(44.9 \%)$ \\
pT4 & $1(0.6 \%)$ \\
Histologic grade & \\
G1 & $20(12.0 \%)$ \\
G2 & $111(66.5 \%)$ \\
G3 & $36(21.6 \%)$ \\
\hline
\end{tabular}

anformation on pT stage was available in 178 of $183(97.3 \%)$ patients. ' Information on grading was available in 167 of 183 $(91.3 \%)$ patients.

performed in a multistep semiautomatic procedure (Ventana NexES automated immunohistochemistry system) as described previously by Wulfing et al (17). Briefly, two polyclonal antibodies for $\mathrm{ET}_{\mathrm{A}} \mathrm{R}$ and $\mathrm{ET}_{\mathrm{B}} \mathrm{R}$ (Alexis Biochemicals Corporation, Lausen, Switzerland) at a dilution of 1:100 for 30 min were used. For ET-1, a monoclonal mouse antibody (CloneTR.ET.48.5, Affinity Bioreagents, Golden, USA) was applied at a 1:500 dilution (25 min) after pretreatment with a steamer for antigen retrieval (Multi-Gourmet, Braun, no. 3216). Specimens were then incubated with a rabbit anti-sheep secondary antibody (Dako; 1:500 for $25 \mathrm{~min}$ ), followed by blocking of endogenous peroxidase $\left(\mathrm{H}_{2} \mathrm{O}_{2}\right.$ for $\left.10 \mathrm{~min}\right)$ and incubation with an Envison ${ }^{\mathrm{TM}}$ Detection kit $(25 \mathrm{~min})$. The enzyme reaction was developed with Chromogen-DAB ( $2 \times 5$ min). Finally, the specimens were counterstained with hematoxylin and mounted with Kayser's glycerine. Ovarian cancer tissue served as positive control for ET-1 staining, prostate cancer tissue for $\mathrm{ET}_{\mathrm{A}} \mathrm{R}$, and smooth muscle tissue for $\mathrm{ET}_{\mathrm{B}} \mathrm{R}$. The specificity of the antibodies was confirmed using omission of the primary antibodies and replacement of the primary antibodies by IgG of the respective species as negative controls. Immunohistochemical staining was independently scored by two investigators from 366 array cores (E.E., H.B.). According to the literature (18), intensities of ET-1, $\mathrm{ET}_{\mathrm{A}} \mathrm{R}$ and $\mathrm{ET}_{\mathrm{B}} \mathrm{R}$ were classified semiquantitatively into different grades on an arbitrary four-tiered scale of 0 to $3+$. We defined tumour samples with weak $(1+)$, moderate $(2+)$ or strong (3+) immunostaining intensity to have an elevated ET-1, $\mathrm{ET}_{\mathrm{A}} \mathrm{R}$ or $\mathrm{ET}_{\mathrm{B}} \mathrm{R}$ expression, and thus to be positive (Fig. 1).

Data analysis. Staining intensity was evaluated semiquantitatively in a blind fashion. For statistical analysis SPSS for Windows $^{\mathrm{TM}}$ (Version 13.0) was used. All histopathologic parameters were correlated with staining results by means of cross-tables applying Chi-Square and Fisher's exact test. Correlations between the two different samples from identical tumours were tested to investigate variance of expression. A $\mathrm{p}<0.05$ was considered statistically significant. 


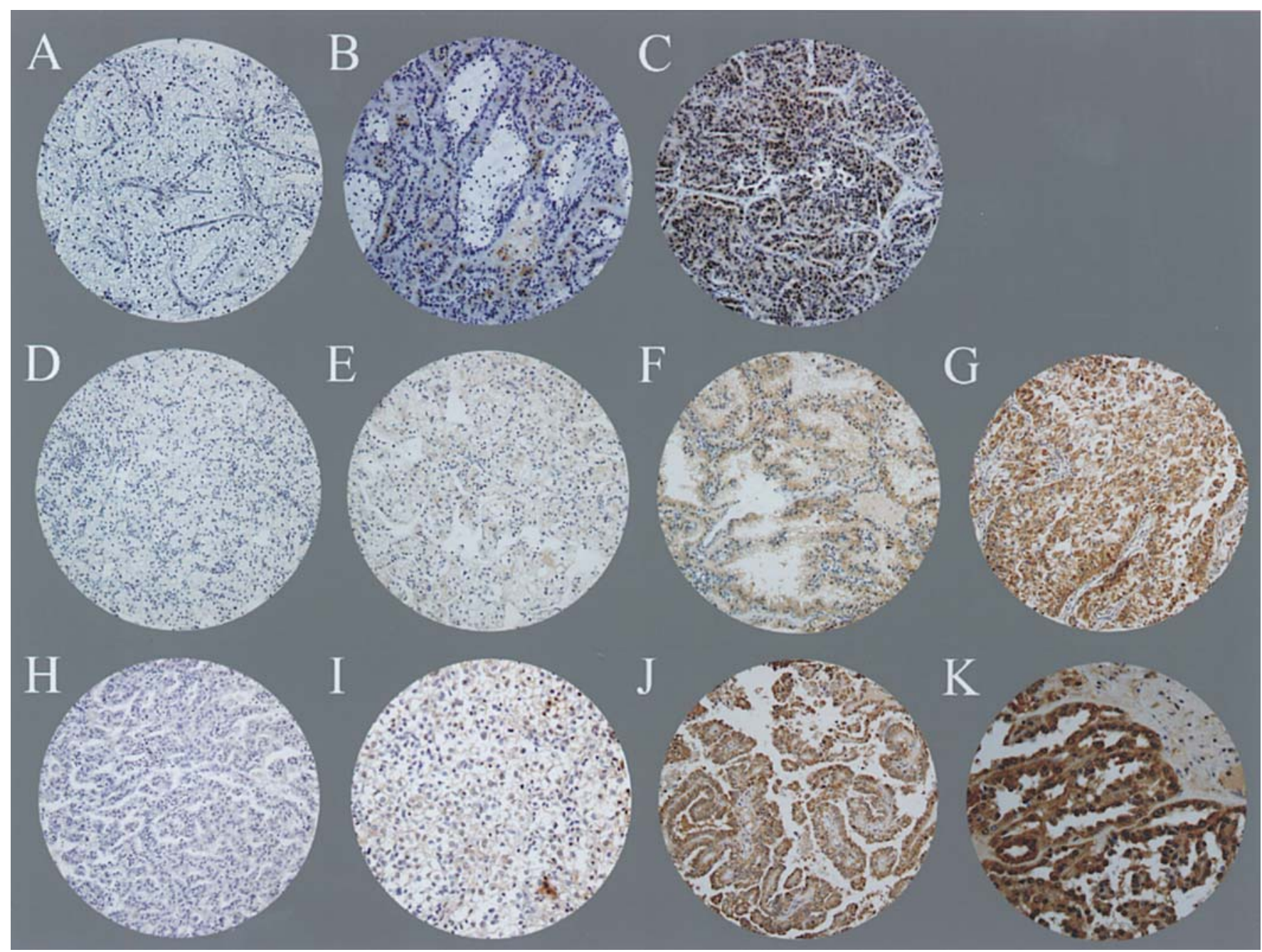

Figure 1. Representative examples of staining for ET-1 (A, negative; B, weak; C, moderate), $\mathrm{ET}_{\mathrm{A}} \mathrm{R}$ (D, negative; $\mathrm{E}$, weak; $\mathrm{F}$, moderate; $\mathrm{G}$, strong) and $\mathrm{ET}_{\mathrm{B}} \mathrm{R}$ (H, negative; I, weak; J, moderate; K, strong) (images reduced from x20).

\section{Results}

Immunohistochemical analysis of $E T-1, E T_{A} R$ and $E T_{B} R$ expression. From the 183 patients, $\mathrm{ET}-1, \mathrm{ET}_{\mathrm{A}} \mathrm{R}$ and $\mathrm{ET}_{\mathrm{B}} \mathrm{R}$ staining status was available in $180(98.4 \%), 182(99.5 \%)$ and $180(98.4 \%)$ cases, respectively. In the missing cases, tissue had been lost during steamer-pre-treatment or the core samples did not contain a sufficient number of tumour cells. Staining intensity of ET-1, $\mathrm{ET}_{\mathrm{A}} \mathrm{R}$, and $\mathrm{ET}_{\mathrm{B}} \mathrm{R}$ among different samples varied from complete absence of staining to strong staining. Endothelin-1 staining was identified in $12.8 \%$ of cases; expression of $\mathrm{ET}_{\mathrm{A}} \mathrm{R}$ and $\mathrm{ET}_{\mathrm{B}} \mathrm{R}$ was increasingly frequent (84.1\% and $93.3 \%$, respectively). Predominantly the staining patterns were either weak or moderate (Table II).

Correlation with pathologic parameters. From the 183 specimens, we were able to define the histologic subtype in $176(96.2 \%)$ of cases. Of the RCCs, $135(73.8 \%)$ were of clear cell and $30(17.1 \%)$ were of papillary origin. Sarcomatoid tumours were found in $6(3.4 \%)$ and chromophobe tumours in $5(2.8 \%)$ cases. ET-1 expression did not correlate with tumour stage and histologic grade; pRCC expressed highly significantly more ET- 1 than ccRCC $(34.5 \%$ vs. $6.7 \%$,
Table II. Distribution of staining patterns for ET-1, $\mathrm{ET}_{\mathrm{A}} \mathrm{R}$ and $\mathrm{ET}_{\mathrm{B}} \mathrm{R}$.

\begin{tabular}{lccc}
\hline & \multicolumn{3}{c}{$\mathrm{n}(\%)$} \\
\cline { 2 - 4 } & $\begin{array}{c}\mathrm{ET}-1 \\
(\mathrm{n}=180)\end{array}$ & $\begin{array}{c}\mathrm{ET}_{\mathrm{A}} \mathrm{R} \\
(\mathrm{n}=182)\end{array}$ & $\begin{array}{c}\mathrm{ET}_{\mathrm{B}} \mathrm{R} \\
(\mathrm{n}=183)\end{array}$ \\
\hline Score & & & \\
0 & $157(87.2 \%)$ & $29(15.9 \%)$ & $12(6.7 \%)$ \\
$1+$ & $21(11.7 \%)$ & $105(57.8 \%)$ & $77(42.7 \%)$ \\
$2+$ & $2(1.1 \%)$ & $47(25.8 \%)$ & $84(46.7 \%)$ \\
$3+$ & $0(0.0 \%)$ & $1(0.5 \%)$ & $7(3.9 \%)$ \\
Negative (score 0) & $157(87.2 \%)$ & $29(15.9 \%)$ & $12(6,7 \%)$ \\
Positive (score 1-3) & $23(12.8 \%)$ & $153(84.1 \%)$ & $171(93,3 \%)$ \\
\hline
\end{tabular}

$\mathrm{p}<0.001)$. Although there was no association with tumour size or histologic subtype, $\mathrm{ET}_{\mathrm{A}} \mathrm{R}$ tended to be overexpressed in the subgroup of $\mathrm{G} 3$-tumors $(\mathrm{p}=0.044) . \mathrm{ET}_{\mathrm{B}} \mathrm{R}$ was the 
Table III. Association of positive ET-1, $\mathrm{ET}_{\mathrm{A}} \mathrm{R}$ and $\mathrm{ET}_{\mathrm{B}} \mathrm{R}$ expression with histopathological variables.

\begin{tabular}{|c|c|c|c|c|c|c|}
\hline Pathological variables & $\begin{array}{c}\text { ET-1 staining n } \\
\text { positive/total }(\%)\end{array}$ & $\mathrm{p}^{\mathrm{a}}$ & $\begin{array}{l}\mathrm{ET}_{\mathrm{A}} \mathrm{R} \text { staining } \mathrm{n} \\
\text { positive/total }(\%)\end{array}$ & $\mathrm{p}^{\mathrm{a}}$ & $\begin{array}{l}\mathrm{ET}_{\mathrm{B}} \mathrm{R} \text { staining } \mathrm{n} \\
\text { positive/total }(\%)\end{array}$ & $\mathrm{p}^{\mathrm{a}}$ \\
\hline \multicolumn{7}{|l|}{ Tumor stage } \\
\hline pT1 & $10 / 76(13.2 \%)$ & 0.65 & $63 / 76(82.9 \%)$ & 0.69 & $73 / 76(96.1 \%)$ & 0.43 \\
\hline pT2 & $4 / 21(19.0 \%)$ & & $16 / 21(76.2 \%)$ & & $18 / 21(85.7 \%)$ & \\
\hline pT3 & $8 / 77(10.4 \%)$ & & $69 / 79(87.3 \%)$ & & $72 / 77(93.5 \%)$ & \\
\hline pT4 & $0 / 1(0.0 \%)$ & & $1 / 1(100.0 \%)$ & & $1 / 1(100.0 \%)$ & \\
\hline \multicolumn{7}{|l|}{ Histologic grade } \\
\hline G1 & $5 / 20(25.0 \%)$ & 0.31 & $17 / 20(85,0 \%)$ & 0.04 & $19 / 20(95 \%)$ & 0.57 \\
\hline $\mathrm{G} 2$ & $12 / 109(11.0 \%)$ & & $90 / 119(81,8 \%)$ & & $102 / 109(93.6 \%)$ & \\
\hline G3 & 4/35 (11.4\%) & & $34 / 36(94.4 \%)$ & & $32 / 35(91.4 \%)$ & \\
\hline \multicolumn{7}{|l|}{ Histology type } \\
\hline $\mathrm{ccRCC}$ & $9 / 133(6.8 \%)$ & 0.001 & $112 / 135(83.0 \%)$ & 0.52 & $126 / 133(94.7 \%)$ & 0.13 \\
\hline $\mathrm{pRCC}$ & $10 / 29(34.5 \%)$ & & $26 / 29(89.7 \%)$ & & $27 / 29(93.1 \%)$ & \\
\hline Sarcomatoid & $2 / 6(33.3 \%)$ & & $6 / 6(100.0 \%)$ & & $5 / 6(83.3 \%)$ & \\
\hline Chromophobe & $0 / 5(0.0 \%)$ & & $3 / 5(60.0 \%)$ & & $1 / 5(20.0 \%)$ & \\
\hline
\end{tabular}

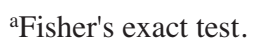

predominant receptor in this TMA but it still did not show any association with tumour size, histologic grading or histologic subtype. A comprehensive summary of the staining patterns of ET-1, $\mathrm{ET}_{\mathrm{A}} \mathrm{R}$ and $\mathrm{ET}_{\mathrm{B}} \mathrm{R}$ and their association with several pathologic variables is shown in Table III.

\section{Discussion}

RCC is the sixth leading cause of cancer deaths and the most lethal urologic cancer in the developed nations. RCC accounts for 2-3\% of cancer incidence and results in over 100,000 worldwide deaths annually (19). RCC age-adjusted incidence has been rising for the past 30 years within the US and most European nations at an annual rate of approximately $3 \%$ (19). For those who present with metastases, the overall clinical course of RCC varies; approximately $50 \%$ of patients survive less than 1 year and $10 \%$ survive for over 5 years (20). In the past two decades, management of the disease has undergone considerable change. Chemotherapy has consistently been an ineffective form of treatment, and until recently, the only effective treatment for metastatic disease was cytokine-based immunotherapy with interferon (IFN)- $\alpha$ or interleukin (IL)-2, which have a response rate of approximately $15 \%$ (21). Advances in understanding tumour biology and genetics of metastatic RCC have led to several novel targeted approaches with higher response rates for agents such as Sunitinib (SU11248) and Sorafenib (BAY 43-9006), which were recently approved in the US and some European states (22). In phase II clinical trials these targeted agents had an overall response rate of up to $40 \%$ (22). Unfortunately, the clinical response to these agents was not permanent; rather the time to progression was, on average, approximately 6-12 months
(22). The results of the clinical trials led to the statement that further molecular targets need to be identified for targeted therapy and improve the prognosis of patients with metastatic RCC.

ET-1 and its receptors $\mathrm{ET}_{\mathrm{A}} \mathrm{R}$ and $\mathrm{ET}_{\mathrm{B}} \mathrm{R}$, have recently been demonstrated to be overexpressed in various human tumours such as bladder, ovarian, cervical, breast, colon and lung cancers, as well as in melanomas $(6,7)$. It has been clearly shown that the ET-axis functions in the growth and progression of cancer by influencing apoptosis, angiogenesis and several growth factors (6). The emerging role of the ET-axis in cancer has led to the development of selective ET receptor antagonists for targeted molecular therapy, and results of clinical trials were promising for Atrasentan in the treatment of hormone-refractory prostate cancer (13).

In the kidney, ET-1 is secreted by a number of different tissue compartments, including blood vessels, glomeruli, tubules and collecting ducts. $\mathrm{ET}_{\mathrm{A}} \mathrm{R}$ and $\mathrm{ET}_{\mathrm{B}} \mathrm{R}$ are found in the same cells, but also exist in juxtaglomerular and mesangial cells (23). The most common histologic subtypes of RCC are ccRCC and pRCC. A number of distinguishing features at the macroscopic, microscopic and cytogenetic levels have been recognized that suggest these tumours differ significantly. They include the hypervascular nature of ccRCC compared with the characteristically hypovascular appearance of pRCC, the presence of infiltrating lymphocytes and macrophages in pRCC but not ccRCC, and the increased incidence of necrosis in patients with pRCC but not ccRCC (14). Distinct karyotopic aberrations also set these subtypes apart, such as loss of $3 p$ in ccRCC compared with trisomies of 7, 12, 16, 17 and 20 and loss of the Y chromosome in pRCC $(2,3,24)$. Some authors have reported less favourable clinical outcomes in patients with 
papillary tumours (25). Other authors suggested a significantly favourable outcome for patients with pRCC compared to ccRCC (26). In the latest study to date, Patard et al (27) initiated a multicenter study with 4063 patients to examine the prognostic value of histologic subtypes in RCC; papillary and clear cell tumours were not found to have a significantly different outcome in distant disease.

In RCC, to our knowledge, the ET-axis is described in only three small studies. In 1999 Thevarajah et al examined its expression in six RCC cell lines by enzyme linked immunosorbent assay (ELISA) for ET-1 and RT-PCR confirmed by Southern blot hybridization for $\mathrm{ET}_{\mathrm{A}} \mathrm{R}$ and $\mathrm{ET}_{\mathrm{B}} \mathrm{R}$ mRNA. Relatively large amounts of ET-1 were secreted. All cell lines expressed $\mathrm{ET}_{\mathrm{A}} \mathrm{R}$ mRNA, while three cell lines also expressed $\mathrm{ET}_{\mathrm{B}} \mathrm{R}$ mRNA. ET-1 binding was limited to $\mathrm{ET}_{\mathrm{A}} \mathrm{R}$ (15). In another small study with 35 specimens, Douglas et al demonstrated gene expression for preproendothelin (PPET)$1,-2$ and -3 , the receptors $\mathrm{ET}_{\mathrm{A}} \mathrm{R}$, and $\mathrm{ET}_{\mathrm{B}} \mathrm{R}$ and endothelinconverting-enzyme (ECE)-1 and -2. PPET-1 was upregulated in ccRCC and downregulated in pRCC. $\mathrm{ET}_{\mathrm{A}} \mathrm{R}$ was downregulated significantly in pRCC (14). Recently, Pflug et al were able to find relatively high levels of ET-1 and $\mathrm{ET}_{\mathrm{A}} \mathrm{R}$ mRNA in six RCC cell lines, while $3 / 6$ cell lines also expressed $\mathrm{ET}_{\mathrm{B}} \mathrm{R}$ mRNA. Furthermore they demonstrated that ET-1 signaling in RCC induces protection from apoptosis through inducing the P13-kinase pathway and activating Akt. Finally, they concluded that the use of $\mathrm{ET}_{\mathrm{A}} \mathrm{R}$ antagonists to inhibit the antiapoptotic functions of ET-1 signaling may induce increased sensitivity to chemotherapeutics in vivo and recommended therapeutic targeting of $\mathrm{ET}_{\mathrm{A}} \mathrm{R}$ as a novel treatment strategy for RCC (16).

In the present study, which is the first to apply standard immunohistochemical techniques, ET-1 was highly significantly overexpressed in pRCC compared to ccRCC $(\mathrm{p}<0.001)$. These data are controversial to former findings describing gene expression (14), where PPET-1 was overexpressed in ccRCC and impaired in pRCC. Furthermore Douglas et al described a downregulation of $\mathrm{ET}_{\mathrm{A}} \mathrm{R}$ in $\mathrm{pRCC}$, which again cannot be confirmed by our results (14). Reviewing recent data, ET-1 is synthesised via proteolytic cleavage of PPET-1, which is facilitated by the metalloproteinase, endothelin converting enzyme (ECE). Entering this pathway, ET-1 modulates mitogenesis, apoptosis, angiogenesis, tumour invasion and development of metastasis with high affinity to its receptor $\mathrm{ET}_{\mathrm{A}} \mathrm{R}$, while $\mathrm{ET}_{\mathrm{B}} \mathrm{R}$ does not show selective affinity for any of the ET subtypes (ET-1, ET-2 and ET-3) (28). ET-1 has been shown to stimulate the growth of several human cancer cell lines in vitro (29-31) via $\mathrm{ET}_{\mathrm{A}} \mathrm{R}$ in epithelial tumours $(29,30)$ and via $\mathrm{ET}_{\mathrm{B}} \mathrm{R}$ in melanoma cells $(31)$. In vivo, antagonism of $\mathrm{ET}_{\mathrm{B}} \mathrm{R}$ was shown to significantly slow down melanoma tumour growth in nude mice (32). ET-1 also acts as a mitogen for both endothelial cells and vascular smooth muscle cells and stimulates VEGF production by other cell types (18). Bek et al were able to inhibit ET-1 stimulated angiogenesis by $\mathrm{ET}_{\mathrm{A}} \mathrm{R}$ antagonism in mice (33). Overexpression of ET-1 is associated with tumour invasion and metastases; it modulates the growth of bone metastases from prostate cancer (34). From the evidence to date on ET-1 expression in epithelial tumours, it appears that selective
$\mathrm{ET}_{\mathrm{A}} \mathrm{R}$ antagonism provides the most likely effective method of endothelin inhibition (28). As renal cell carcinoma belongs to the group of epithelial tumours and $\mathrm{ET}_{\mathrm{A}} \mathrm{R}$ is overexpressed in $84.1 \%$ of cases, the effects in tumour biology described above might be blocked by $\mathrm{ET}_{\mathrm{A}} \mathrm{R}$ antagonism in this tumour entity. Patients with pRCC and significant overexpression of ET-1 $(34.5 \%)$ compared to ccRCC $(6.7 \%)(\mathrm{p}<0.001)$ or patients with G3-tumors of either histologic subtype and upregulated $\mathrm{ET}_{\mathrm{A}} \mathrm{R}$ expression $(94.4 \%)(\mathrm{p}=0.044)$ as in the present study might benefit from this type of molecular targeted therapy. The other receptor, $\mathrm{ET}_{\mathrm{B}} \mathrm{R}$, is predominantly expressed in $93.3 \%$ of cases; this is consistent with data on breast cancer, where $\mathrm{ET}_{\mathrm{B}} \mathrm{R}$ was expressed more frequently than $\mathrm{ET}_{\mathrm{A}} \mathrm{R}$ (53.4\% vs. $46.5 \%$, repectively) (17). In accordance with our data, $\mathrm{ET}_{\mathrm{B}} \mathrm{R}$ is also the predominant receptor in melanoma and lung cancer $(6,7)$.

Our results show that the ET-axis is overexpressed in RCC with ET-1 being highly significantly upregulated in pRCC and $\mathrm{ET}_{\mathrm{A}} \mathrm{R}$ in the subgroup of G3-tumors. The exact biochemical link between expression of the ET-axis, distribution and regulation of the ET receptors, and influence on apoptosis, angiogenesis and proliferation in RCC remains unclear. The effect of the ET-axis on clinical outcome and prognosis is currently under investigation at our institution. Moreover, further preclinical and clinical studies will be initiated to elucidate whether the ET-axis can play a role as a prognostic marker and molecular target for renal cell carcinoma.

\section{Acknowledgements}

This study was in part supported by the Research Program of the North Rhine-Westphalian (NRW) Society of Urology, Germany.

\section{References}

1. Drucker BJ: Renal cell carcinoma: current status and future prospects. Cancer Treat Rev 31: 536-545, 2005.

2. Storkel S, Eble JN, Adlakha K, et al: Classification of renal cell carcinoma: Workgroup No. 1 Union Internationale Contre le Cancer (UICC) and the American Joint Committee on Cancer (AJCC). Cancer 80: 987-989, 1997.

3. Higgins JP, Shinghal R, Gill H, et al: Gene expression patterns in renal cell carcinoma assessed by complementary DNA microarray. Am J Pathol 162: 925-932, 2003.

4. Yanagisawa M, Kurihara H, Kimura S, et al: A novel potent vasoconstrictor peptide produced by vascular endothelial cells. Nature 332: 411-415, 1988

5. Kusuhara M, Yamaguchi K, Nagasaki K, et al: Production of endothelin in human cancer cell lines. Cancer Res 50: 3257-3261, 1990.

6. Nelson J, Bagnato A, Battistini B and Nisen P: The endothelin axis: emerging role in cancer. Nat Rev Cancer 3: 110-116, 2003.

7. Herrmann E, Bogemann M, Bierer S, Eltze E, Hertle L and Wulfing C: The endothelin axis in urologic tumors: mechanisms of tumor biology and therapeutic implications. Expert Rev Anticancer Ther 6: 73-81, 2006.

8. Spinella F, Rosano L, Di Castro V, Natali PG and Bagnato A: Endothelin-1 induces vascular endothelial growth factor by increasing hypoxia-inducible factor-1 alpha in ovarian carcinoma cells. J Biol Chem 277: 27850-27855, 2002.

9. Wulfing C, Eltze E, Piechota H, et al: Expression of endothelin-1 and endothelin-A and -B receptors in invasive bladder cancer. Oncol Rep 13: 223-228, 2005.

10. Wulfing C, Eltze E, Yamini J, et al: Expression of the endothelin axis in bladder cancer: relationship to clinicopathologic parameters and long-term survival. Eur Urol 47: 593-600, 2005. 
11. Nelson JB, Hedican SP, George DJ, Reddi AH, Piantadosi S, Eisenberger MA and Simons JW: Identification of endothelin-1 in the pathophysiology of metastatic adenocarcinoma of the prostate. Nat Med 1: 944-949, 1995.

12. Carducci MA, Padley RJ, Breul J, et al: Effect of endothelin-A receptor blockade with atrasentan on tumor progression in men with hormone-refractory prostate cancer: a randomized, phase II, placebo-controlled trial. J Clin Oncol 21: 679-689, 2003.

13. Jimeno A and Carducci M: Atrasentan: a novel and rationally designed therapeutic alternative in the management of cancer. Expert Rev Anticancer Ther 5: 419-427, 2005.

14. Douglas ML, Richardson MM and Nicol DL: Endothelin axis expression is markedly different in the two main subtypes of renal cell carcinoma. Cancer 100: 2118-2124, 2004.

15. Thevarajah S, Udan MS, Zheng $\mathrm{H}$ and Nelson JB: Endothelin axis expression in renal cell carcinoma. J Urol 161: 137-143, 1999.

16. Pflug BR, Zheng H, Udan MS, D'Antonio JM, Marshall FF, Brooks JD and Nelson JB: Endothelin-1 promotes cell survival in renal cell carcinoma through the ET(A) receptor. Cancer Lett (Epub ahead of print), 2006.

17. Wulfing P, Diallo R, Kersting C, et al: Expression of endothelin-1, endothelin-A, and endothelin-B receptor in human breast cancer and correlation with long-term follow-up. Clin Cancer Res 9: 4125-4131, 2003.

18. Salani D, Di Castro V, Nicotra MR, et al: Role of endothelin-1 in neovascularization of ovarian carcinoma. Am J Pathol 157: $1537-1547,2000$.

19. Chow WH, Devesa SS, Warren JL and Fraumeni JF: Rising incidence of renal cell cancer in the United States. JAMA 281: 1628-1631, 1999

20. Motzer RJ, Bacik J and Mazumdar M: Prognostic factors for survival of patients with stage IV renal cell carcinoma: memorial sloan-kettering cancer center experience. Clin Cancer Res 10: 6302-6303, 2004.

21. Rosenberg SA, Lotze MT, Muul LM, et al: A progress report on the treatment of 157 patients with advanced cancer using lymphokine-activated killer cells and interleukin-2 or high-dose interleukin-2 alone. N Engl J Med 316: 889-897, 1987.

22. Patel PH, Chaganti RS and Motzer RJ: Targeted therapy for metastatic renal cell carcinoma. Br J Cancer 94: 614-619, 2006.
23. Sullivan ME, Mumtaz FH, Khan MA, Dashwood MR, Thompson CS, Mikhailidis DP and Morgan RJ: Endothelins in the urinary tract. BJU Int 86: 97-106, 2000

24. Meloni-Ehrig AM: Renal cancer: cytogenetic and molecular genetic aspects. J Med Genet 115: 164-172, 2002.

25. Ljungberg B, Alamdari FI, Stenling R and Roos G: Prognostic significance of the Heidelberg classification of renal cell carcinoma. Eur Urol 36: 565-569, 1999.

26. Cheville JC, Lohse CM, Zincke H, Weaver AL and Blute ML: Comparisons of outcome and prognostic features among histologic subtypes of renal cell carcinoma. Am J Surg Pathol 27: 612-624, 2003.

27. Patard JJ, Leray E, Rioux-Leclercq N, et al: Prognostic value of histologic subtypes in renal cell carcinoma: a multicenter experience. J Clin Oncol 23: 2763-2771, 2005.

28. Grant K, Loizidou M and Taylor I: Endothelin-1: a multifunctional molecule in cancer. Br J Cancer 88: 163-166, 2003.

29. Nelson JB, Chan-Tack K, Hedican SP, Magnuson SR, Opgenorth TJ, Bova GS and Simons JW: Endothelin-1 production and decreased endothelin B receptor expression in advanced prostate cancer. Cancer Res 56: 663-668, 1996.

30. Bagnato A, Salani D, Di Castro V, et al: Expression of endothelin-1 and endothelin A receptor in ovarian carcinoma: evidence for an autocrine role in tumor growth. Cancer Res 59: 720-727, 1999.

31. Kikuchi K, Nakagawa H, Kadono T, et al: Decreased ET(B) receptor expression in human metastatic melanoma cells. Biochem Biophys Res Commun 219: 734-739, 1996.

32. Lahav R, Heffner G and Patterson PH: An endothelin receptor B antagonist inhibits growth and induces cell death in human melanoma cells in vitro and in vivo. Proc Natl Acad Sci USA 96: 11496-11500, 1999.

33. Bek EL and McMillen MA: Endothelins are angiogenic. J Cardiovasc Pharmacol 36: 135-139, 2000.

34. Nelson, JB, Nguyen SH, Wu-Wong JR, Opgenorth TJ, Dixon DB, Chung LW and Inoue N: New bone formation in an osteoblastic tumor model is increased by endothelin-1 overexpression and decreased by endothelin A receptor blockade. Urology 53: 1063-1069, 1999. 